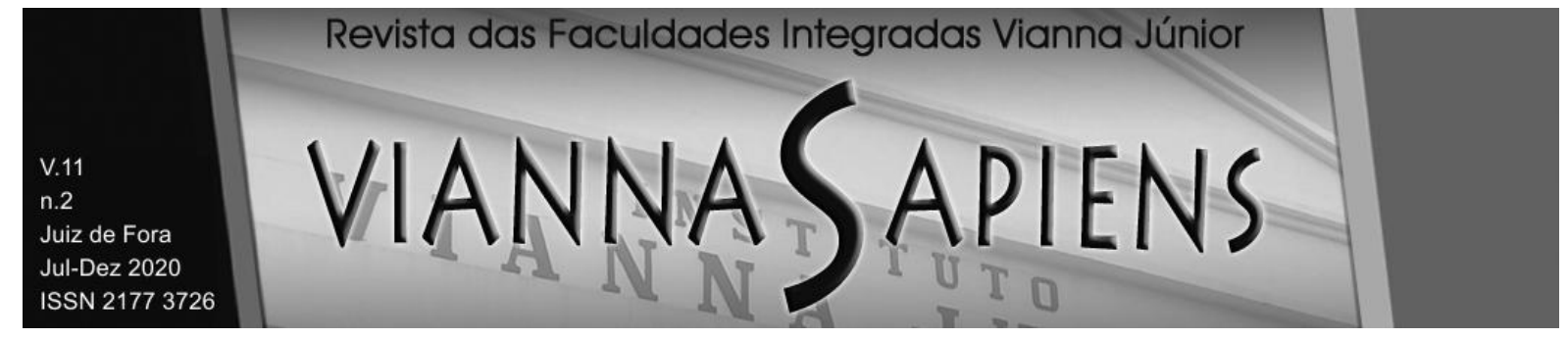

\title{
A renunciabilidade do direito constitucional do júri popular em face da
} influência midiática

DOI: 10.31994/rvs.v11i2.656

\author{
Almir Santos Reis Junior \\ Bruno Humphreys Lobo da Costa Prado*
}

\section{RESUMO}

O presente trabalho tem como objetivo analisar se a mídia brasileira influencia as decisões tomadas no Tribunal do Júri bem como se os casos colocados em circulação midiática têm grande repercussão já com juízo de valor da própria imprensa, prejudicando a análise da verdade real dos fatos. $O$ trabalho apresenta casos concretos com a finalidade de verificar se a mídia realmente influencia jurados leigos. A problemática maior é encontrar mecanismo que garanta a imparcialidade dos julgadores na apreciação e julgamento de crimes dolosos contra a vida, ou seja, não deixar que a "voz publicada" e não "voz pública" seja mola propulsora da parcialidade e pré-julgamento de seres humanos. Para tanto, foi utilizado o método lógico-dedutivo e foram realizadas pesquisas na doutrina e jurisprudência. Concluiuse que por diversas vezes o Tribunal do Júri é usado como instrumento de opressão e exclusão, manipulado pela mídia, para seguir a vontade popular, razão pela qual torna-se necessária a criação de mecanismos que possam garantir ao acusado o

\footnotetext{
" Doutor em Direito Penal pela Pontifícia Universidade Católica de São Paulo. Atualmente é professor adjunto do curso de Direito da Universidade Estadual de Maringá (UEM). Atuou como coordenador dos cursos de especialização em Ciências Criminais e Perícias Criminais, ofertados pela PUC/PR, câmpus Maringá. Membro do Conselho Editorial da Editora Juruá (Brasil e Portugal). Parecerista do Conselho Internacional de Estudos Contemporâneos em Pós-Graduação (CONSINTER). Atuou como Presidente da Comissão de Advogados Criminalistas da Ordem dos Advogados do Brasil, subseção de Maringá. E-mail: almir.crime@gmail.com; ORCID: http://orcid.org/0000-0002-6228-274X

Graduado em Direito pela Universidade Estadual de Maringá, no Paraná; e-mail: bhprado0509@gmail.com; ORCID: http://orcid.org/0000-0002-4644-2109
} 


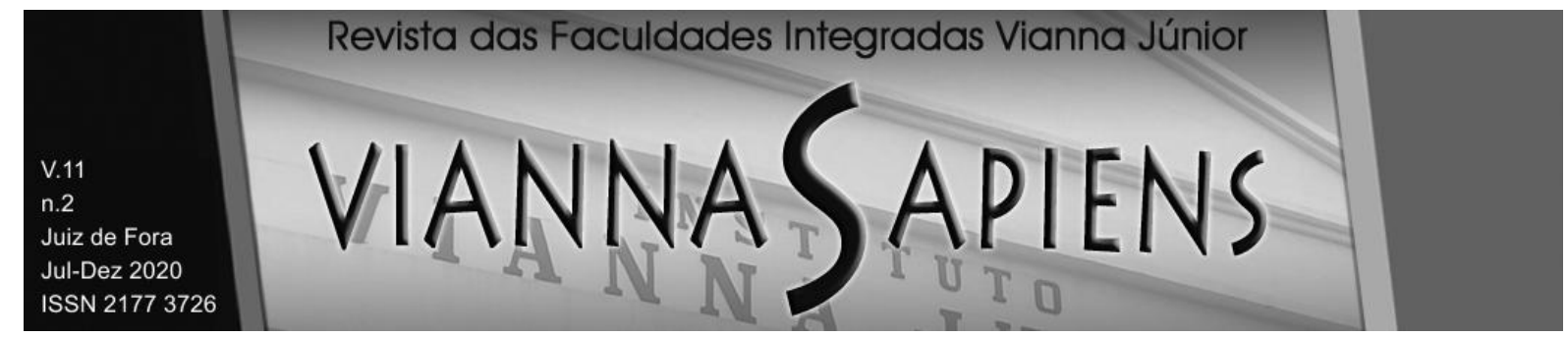

respeito aos seus direitos, tendo em vista que a influência da mídia interfere no convencimento dos jurados, mais do que as próprias provas produzidas em plenário.

\title{
PALAVRAS-CHAVE: PRINCÍPIOS. MÍDIA. PROCESSO PENAL. TRIBUNAL DO JÚRI.
}

\section{The renunciation of the constitutional right of the popular jury in the face of media influence}

\begin{abstract}
The present study aims to demonstrate how the Brazilian midia influences the decisions of a jury trial and how several cases are put in circulation and cause tremendous repercussion already with the midia's opinion, affecting the truth of facts. Thus, this work demonstrates a series of concrete examples in order to check if midia really influences lay jurors. The biggest question is to find mechanisms that can guarantee the impartiality of the judges during the analysis and judgement of felonies committed against civilian lives, not letting the "published voice" be the propulsive string of partiality and pre judgement of human beings, instead of the "public voice". Therefore, it was used the logic-deductive method and researches were carried out with analysis of doctrine and previous court decisions. It was concluded that on several cases a jury trial is used as an instrument of opression and exclusion, manipulated by media to follow the popular will. Therefore, is necessary the creation of mechanisms that can guarantee to the accused respect for his rights, considering that midia's influence interferes the jurors conviction, more than the evidence produced during the plenary session.
\end{abstract}

KEYWORDS: PRINCIPLES. MIDIA. CRIMINAL PROCEDURE. JURY TRIAL. 


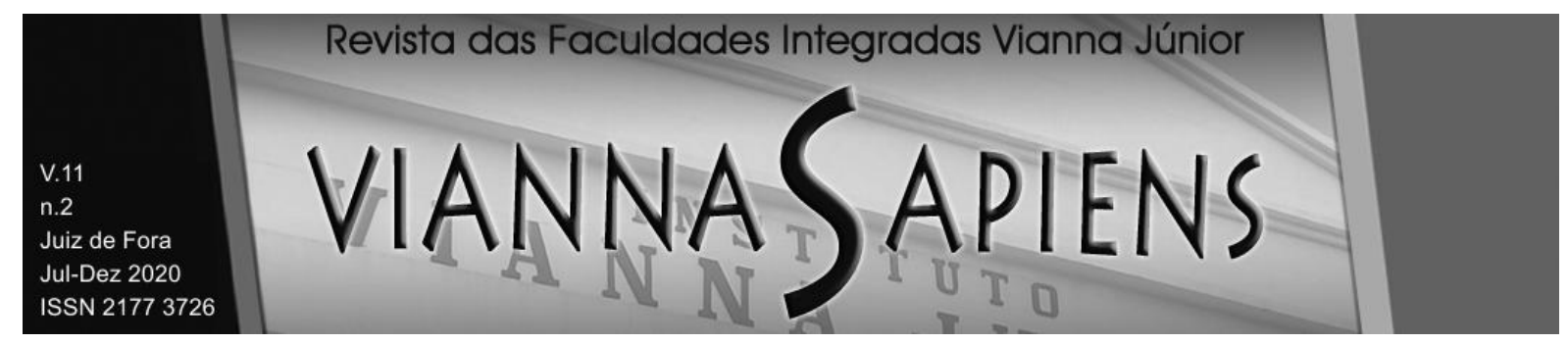

\section{INTRODUÇÃO}

O presente trabalho apresenta o debate sobre a influência da mídia nas decisões do Tribunal do Júri, e suas consequências, considerando que diversos casos concretos são divulgados pela mídia com seu juízo de valor e muitas vezes prejudica a elucidação da verdade real dos fatos, tolhendo o direito a um julgador imparcial.

Será destacado o sistema da íntima convicção dos jurados aplicado à segunda fase do rito do júri. Além disso, será analisada a influência da mídia sobre os jurados e sua consequência durante o julgamento em plenário. Sequencialmente, será apresentado o fair trial e o trial by media, atualmente tratado no direito norteamericano, caracterizado por destacar a grande influência da mídia, o qual já apresenta um pré-julgamento dos acusados, principalmente em casos de grande repercussão, que costumam ocorrer em episódios que envolvam crimes dolosos contra a vida.

Em seguida, serão apresentados alguns casos que possuíram grande repercussão midiática no Brasil, destacando as consequências legais da intervenção midiática sobre o veredito final do Tribunal do Júri e, ao final do último tópico, serão destacadas as contribuições à garantia do devido processo legal no âmbito dos crimes dolosos contra a vida.

Para o desenvolvimento do trabalho, foi utilizado o método lógico-dedutivo, conduzido por meio da análise de referenciais bibliográfico e jurisprudencial.

\section{DA INFORMAÇÃO JORNALíSTICA E SEUS REFLEXOS NO TRIBUNAL DO JÚRI}

É notório que a imprensa tem função essencial em relação à disseminação de acontecimentos cotidianos por todo o país. A cobertura de casos criminais, principalmente quando envolve crime doloso contra a vida, tem nítida preferência do público em geral, uma vez que são casos que geram grande curiosidade e 


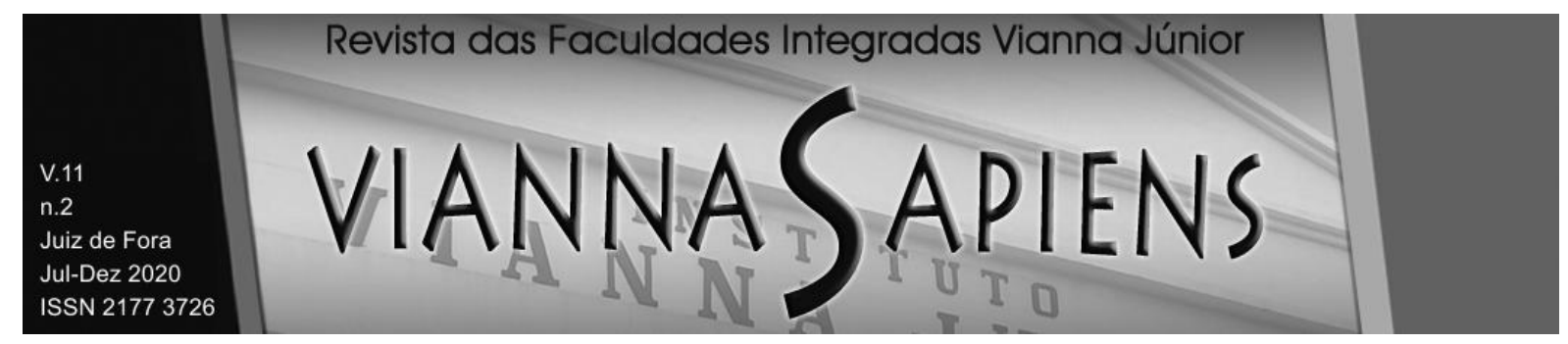

repercussão social, e, na maioria das vezes, cria-se um clamor social pela punição do autor. Nesta esteira de raciocínio, o populismo penal midiático instiga na sociedade o sentimento de vingança; fato que leva ao rompimento dos limites da razoabilidade e da proporcionalidade (ZAFFARONI, 2012).

Assim, como existe grande demanda social por qualquer informação referente a casos criminais, a cobertura feita pela imprensa toma grandes proporções, de modo que, na maioria das vezes, não existe um controle sobre as informações veiculadas.

Muitos veículos de comunicação abusam do ensejo das pessoas por informações e divulgam notícias de acordo com seus próprios interesses, muitas vezes em desalinho ao que realmente ocorreu. A imprensa escolhe não só o que será publicado, mas também o que será ocultado (LIRA, 2014). Diariamente a grande mídia publica relatos que enfatizam o crime e a violência, o que acaba por gerar, cada vez mais, um sentimento de insegurança e clamor pela punição como se isso fosse a solução para frear a criminalidade.

Como consequência, o próprio Poder Judiciário é atingido, uma vez que, nos casos referentes ao Tribunal do Júri, o julgamento é realizado por pessoas leigas, as quais podem ser influenciadas pelos veículos de comunicação.

A linguagem sensacionalista tem a clara intenção de vincular emocionalmente o público por meio de "reportagens chocantes", pois vive financeiramente de noticiários que tolhem seres humanos. Assim, tudo o que é divulgado, seja pela televisão, rádio ou internet, cria um laço com o telespectador, de modo que o sujeito passa a integrar a notícia, se tornando incapaz de discernir o real do sensacional (VIEIRA, 2003). Destarte, pode-se inferir que a imprensa tem nítida interferência nas conviç̧ões dos indivíduos e, por consequência, afeta também a opinião pública, com inegável impacto no Tribunal do Júri, formado por essas mesmas pessoas desprovidas da capacidade de garantir a imparcialidade na discussão e julgamento dos delitos dolosos contra a vida. 


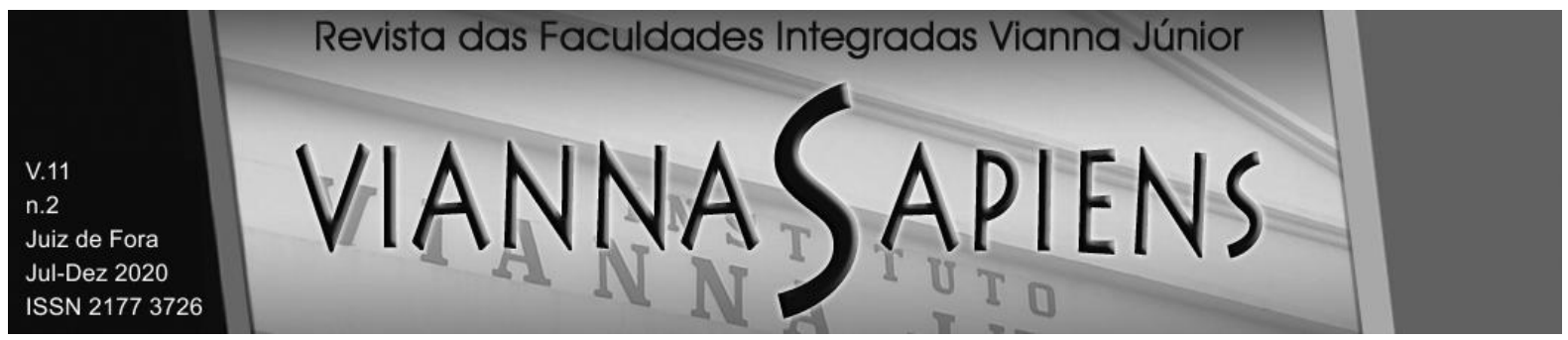

\subsection{Da livre convicção dos jurados}

Em relação à apreciação probatória, vigora no processo penal brasileiro, em regra, o princípio do livre convencimento motivado, pelo qual o magistrado é livre para apreciar e valorar as provas produzidas nos autos, sem se vincular a nenhuma delas, em especial, desde que sua decisão seja fundamentada. Contudo, em relação ao procedimento de competência do Tribunal do Júri, ocorre uma exceção à regra do livre convencimento motivado, tendo em vista que os jurados decidem de acordo com sua íntima conviç̧ão, dispensando, assim, a fundamentação.

A íntima conviç̧ão permite que o julgador tenha plena liberdade para amparar sua escolha, inclusive em elementos que não tenham sido trazidos aos autos, definindo a valoração como bem entender, inexistindo qualquer imposição para que exponha as justificativas de seu julgamento (BONFIM, 2014). Também denominado como certeza moral do juiz, o sistema da íntima convicção é definido por Norberto Avena ( 2017, p. 437) como:

[...] o sistema que confere ao julgador total liberdade na formação de seu convencimento, dispensando-se qualquer motivação sobre as razões que o levaram a esta ou àquela decisão, sendo irrelevante a circunstância de encontrar-se ou não a prova nos autos.

No procedimento especial do Tribunal do Júri não se aplica o princípio do livre convencimento motivado, mas sim, o princípio da prova livre, uma vez que os jurados decidem de modo secreto, não sendo necessário que fundamentem o motivo da escolha ao julgar. Entretanto, não se pode olvidar que os jurados são pessoas leigas, muitas vezes sem formação acadêmica e, por isso, sofrem influências provenientes dos meios de comunicação em massa, de modo que suas percepções podem ser sugestionadas de acordo com as informações que recebem.

Em síntese, nada impede que um jurado realize o julgamento baseado meramente de acordo com suas convicções pessoais, as quais podem facilmente sofrer influência midiática, ainda que isso ocorra de forma inconsciente; tal decisão é eivada de nulidade, pois viola o princípio da imparcialidade do julgador. 


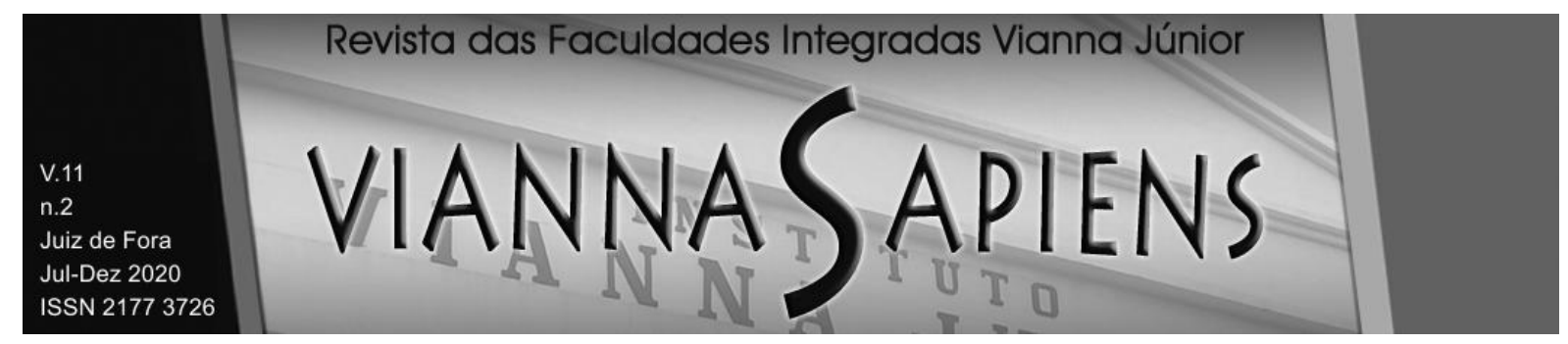

\subsection{A influência midiática na consciência dos juízes naturais}

A imprensa tem influência na concepção de todos que dela têm acesso, seja em maior ou em menor grau. Até mesmo membros do poder judiciário sofrem interferências midiáticas, uma vez que também são humanos e vivem aquilo que ocorre na sociedade, sejam coisas boas ou ruins. Um bom exemplo da interferência midiática no judiciário fica explícito no caso "Isabella Nardoni". Ao manter a prisão cautelar dos acusados Alexandre Nardoni e Anna Carolina Jatobá, o desembargador relator, integrante do Tribunal de Justiça do Estado de São Paulo, admitiu a grande repercussão do caso, bem como a influência da mídia nas convicções do julgador (Habeas Corpus 1.222.269.3/9). Assim sendo, fica patente que, mesmo considerando a preparação que os operadores do direito têm, bem como o acesso e conhecimento completo dos autos e dos procedimentos processuais, além da capacidade suficiente para discernir o que é exposto pela mídia e a realidade processual, até os juízes togados estão sujeitos a interferências provenientes da imprensa (FREITAS, 2018).

Neste diapasão, mais preocupante ainda é intervenção que ocorre no Tribunal do Júri. Se os juízes togados, que possuem uma preparação intensa e diário convívio com os procedimentos legais, em muitos casos acabam cedendo às pressões populares, imagine as pessoas que integram o Conselho de Sentença, que são leigas, do povo, as quais não possuem conhecimento técnico para exprimir apurado juízo de valor acerca das notícias veiculadas pelos grandes meios de comunicação (FREITAS, 2018). Nesta esteira de raciocínio, a verdade é moldada de acordo com aquilo que é constantemente repetido por diversos meios de comunicação em massa e o jurado é levado a crer que se a informação é veiculada por diversas e conhecidas redes comunicativas, consequentemente se trata de uma verdade absoluta.

Ademais, acrescenta-se que o jurado é, em regra, proveniente de um grupo social, cultural e economicamente mais favorecido que a população penal, para julgar um indivíduo menos privilegiado, geralmente tido como um inimigo social, em 


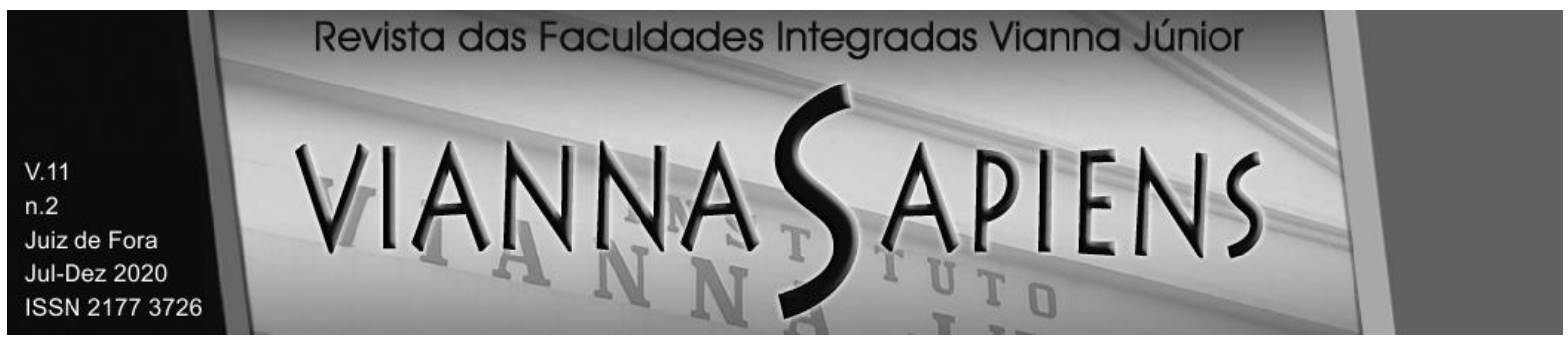

razão da propagação de notícias sensacionalistas e tendenciosas. Acerca dos estereotipados leciona Zaffaroni (2012, p. 315):

Os juízes brandos são o obstáculo para uma luta eficaz contra eles; as garantias penais e processuais são para nós, mas não para eles, pois eles não respeitam os direitos de ninguém. Eles - os estereotipados - não têm direitos, porque matam, não são pessoas, são a escória social, as fezes da sociedade.

O jurado possui acesso limitado aos autos, uma vez que não tem acesso antecipado à íntegra do processo; sua convicção, em tese, deveria se dar apenas pelo que foi exposto pela defesa e pela acusação em plenário, em tempo reduzido. Contudo, no ambiente externo é criado um processo imaginário, cuja presidência se faz por interlocutores midiáticos, sem qualquer qualificação jurídica.

Em adição, frisa-se que o jurado não pode sequer comunicar-se com terceiros e nem dialogar com outro jurado a respeito da valoração das provas durante todo o julgamento, em razão do princípio da incomunicabilidade dos jurados, decorrente do princípio do sigilo das votações, previsto no artigo $5^{\circ}, \mathrm{XXXVIII,} \mathrm{alínea} \mathrm{"b",} \mathrm{da}$ Constituição Federal. Por conseguinte, o jurado acaba se pautando mais pelas referências disseminadas pela imprensa do que nas informações propriamente expostas em plenário. Desta maneira, é evidente que, ao realizar o julgamento, o jurado que compõe o Conselho de Sentença pode receber intensa influência midiática.

\subsection{1 "Fair Trial e Trial by Media"}

A expressão "Trial by Media”, originária dos Estados Unidos, surgiu tendo em vista a enorme influência exercida pela mídia em relação às decisões tomadas pelo Poder Judiciário. Em uma tradução literal, o termo significa "julgamento pela mídia", ou seja, trata-se de um pré-julgamento feito pela imprensa, que ocorre antes mesmo do processo penal, principalmente nos casos de competência do Tribunal do Júri e, em muitas vezes, o autor é considerado culpado pela opinião pública, 


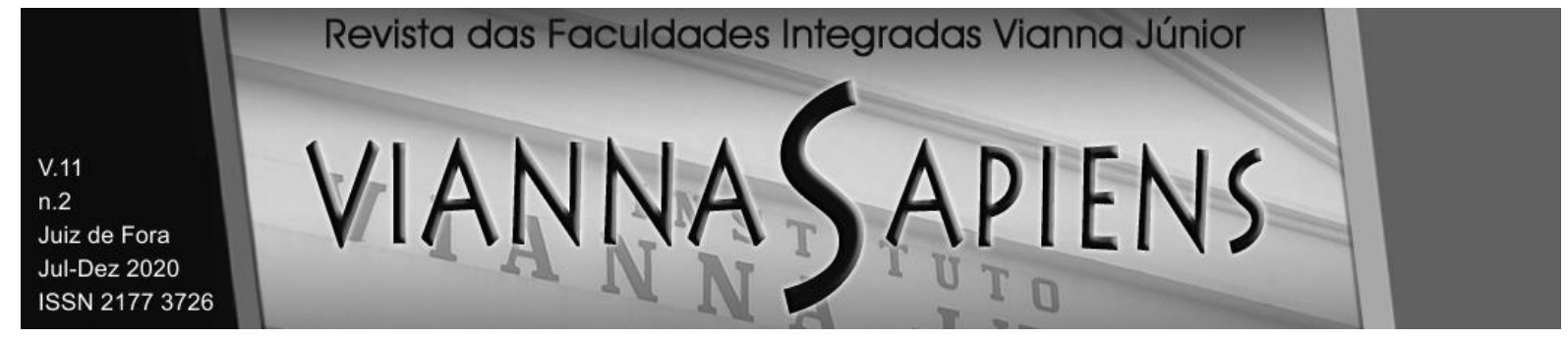

independentemente das provas do processo. Acerca do julgamento midiático, Marília Budó (2013, p. 25) leciona que:

Enquanto o processo judicial instituído é dotado de diversas fases e não pode ser rápido, sob pena de gerar uma decisão baseada em emoções, o processo midiático é frenético e inquisitório: o mesmo órgão investiga, acusa sem defesa, julga e executa a pena de execração pública, de destruição da honra, da vida privada, da imagem, da identidade e, é claro, da presunção de inocência.

Do que se extrai da lição acima colacionada, nota-se que, ao contrário do que deve ocorrer no processo judicial, o processo midiático é baseado no imediatismo e não se preocupa em resguardar garantias pessoais do indivíduo, uma vez que ignora a presunção de inocência, além de invadir a vida privada do acusado, mesmo que isso acarrete em danos irreparáveis a seus direitos personalíssimos.

Neste norte, a Suprema Corte estadunidense possui precedentes nos quais julgamentos criminais foram anulados em decorrência da clara interferência do julgamento midiático na decisão final, o que acarreta em violação ao direito do réu a um julgamento justo, com julgadores imparciais.

Em 1966 houve o emblemático caso Sheppard v. Maxwel (1966), no qual um médico que fora condenado pelo homicídio de sua esposa teve tal condenação anulada pela Suprema Corte, tendo em vista que foi considerada que a cobertura midiática que se deu ao caso foi prejudicial e teve notória influência no resultado final do julgamento. Assim, ao anular a condenação, a Suprema Corte enumerou ações que deveriam ter sido tomadas pelo juiz para que fosse garantido ao réu um julgamento justo, imparcial, livre de interferências da imprensa, por meio do desaforamento ou adiamento do julgamento, a imposição de sequestro e incomunicabilidade dos jurados, além da proibição de que pessoas envolvidas prestassem declarações para a imprensa acerca do julgamento.

De acordo com Simone Schreiber (2010), o Trial by Media é caracterizado por três elementos: o conteúdo da expressão, o potencial risco e a atualidade do julgamento. Em relação ao conteúdo da expressão, observa-se que é formulado um juízo de valor acerca dos fatos, sendo que se sustenta a culpa do acusado, com 


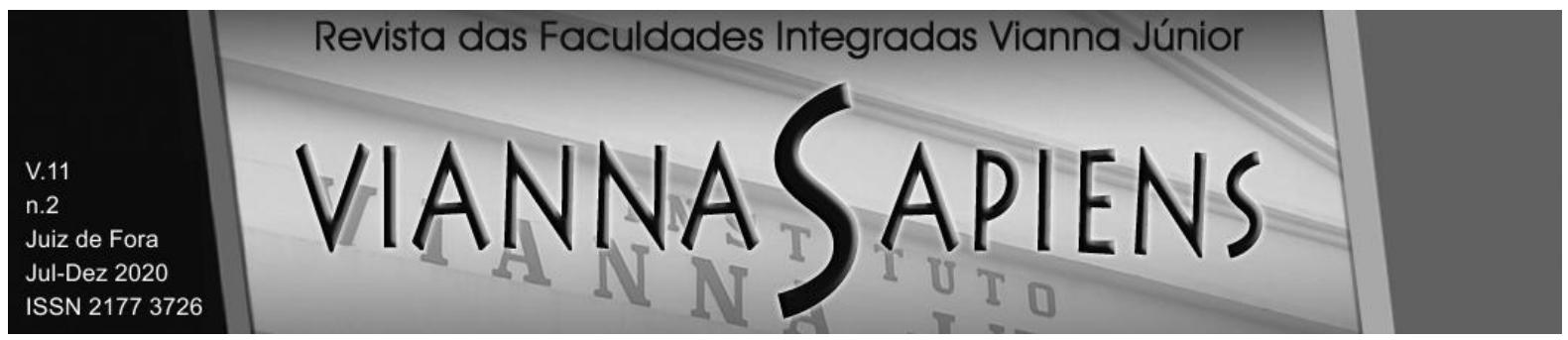

ensejo pela rápida condenação, além de criticar a maneira como a justiça conduz o caso. Frisa-se que, mesmo quando se trata de notícias aparentemente informativas, a divulgação enviesada e manipulada dos fatos acaba por causar prejuízos ao acusado.

O segundo ponto destacado relaciona-se com o potencial risco que as notícias geram aos julgamentos do tribunal, principalmente considerando que os jurados não precisam fundamentar suas decisões, ou seja, decidem também com base nas informações veiculadas pelos grandes meios de comunicação, não atentando-se somente às provas e argumentos trazidos dentro do processo em questão (SCHREIBER, 2010).

Por fim, destaca-se o critério da atualidade da causa, expondo que entre a instauração do inquérito e o julgamento definitivo da causa se dá o período de possível conflito entre a liberdade de expressão e o direito ao julgamento justo. Assim, neste período, surgem reportagens prejudiciais que têm grandes chances de influenciar indevidamente no resultado do julgamento (SCHREIBER, 2010). Logo, observa-se que o julgamento pela mídia ocorre desde a instauração do inquérito, ou até mesmo antes dele, e perdura até a decisão final. Então, os jurados não são influenciados somente no momento do julgamento, mas suportam interferência midiática desde que houve a notícia do fato.

Cumpre destacar que, no Trial by Media, os debates jurídicos são praticamente inexistentes, sendo que o ponto central se dá no apelo emocional, induzindo os espectadores a julgarem os acusados somente com alicerce no que foi informado pela mídia. Desta forma, manipula-se a opinião pública ao estabelecer o lado do bem e o lado do mal, conforme exposto por Nilo Batista (2003, p. 256):

[...] uma acusação a alguém se torna pública não é absolutamente neutro nem puramente descritivo. A acusação vem servida com seus ingredientes já demarcados por um olhar moralizante e maniqueísta; o campo do mal destacado do campo do bem, anjos e demônios em sua primeira aparição inconfundíveis. 


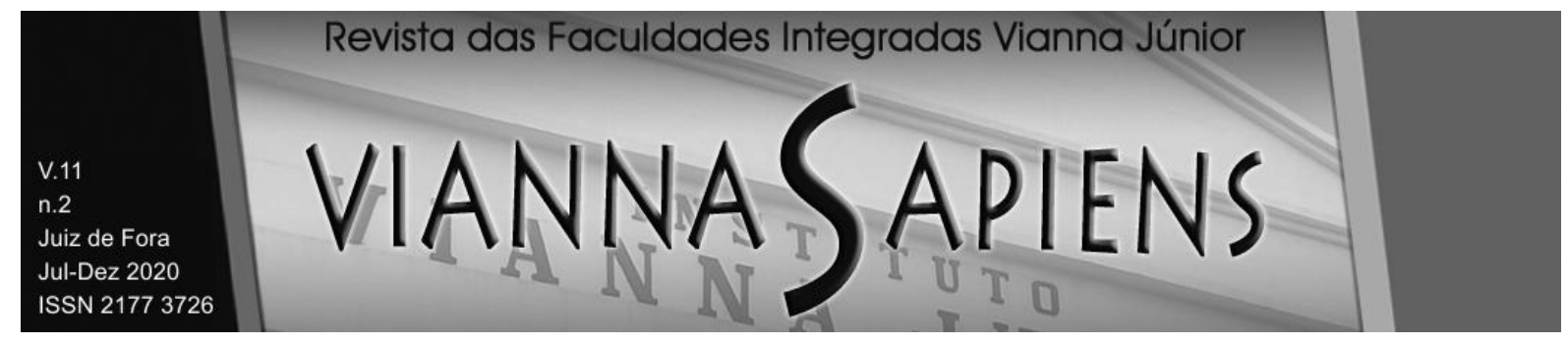

Assim sendo, ao propagar conteúdos sensacionalistas e enviesados, a mídia antecipa o julgamento do acusado, da forma que lhe convém, uma vez que escolhe as informações que serão ou não veiculadas, bem como a forma e a intensidade da propagação da notícia, fazendo com que a opinião pública atinja um julgamento precipitado, antes mesmo que o exame ocorra pelo Poder Judiciário.

Em adição, o populismo midiático tem como característica a grande exposição dos envolvidos, principalmente dos acusados; a cobertura destaca elementos independentemente de sua relevância penal, como características da personalidade, relações pessoais e aparência física do indivíduo, com grande ênfase sensacionalista (PINA, 2009). Deste modo, é claro que a interferência midiática pode até mesmo "representar um perigo mais real para a independência da justiça que eventuais ingerências do Poder Executivo" (SANGUINÉ apud ANDRADE, 2007).

Destarte, o Trial by Media é um fenômeno no qual os meios de comunicação realizam o pré-julgamento do acusado, principalmente em eventos de grande repercussão, como ocorre nos casos de competência do Tribunal do Júri, sendo o acusado considerado culpado pela opinião pública, antes mesmo do julgamento perante o Poder Judiciário, independentemente de sua real culpabilidade.

Assim, o julgamento midiático acaba por entrar em forte conflito com os direitos relativos à presunção de inocência e ao devido processo legal, sendo, portanto, extremamente prejudicial ao acusado.

\subsection{Apontamentos sobre casos de grande repercussão midiática e seus impactos no (in) devido processo legal}

Como analisado nos tópicos anteriores, os meios de comunicação em massa elegem os casos que terão destaque de acordo com o potencial interesse que o público dará. Geralmente, os casos que mais chamam atenção e despertam curiosidade popular são aqueles que envolvem violência, de modo que os crimes de competência do Tribunal do Júri são sempre fortes noticiários para figurarem nos tabloides e manchetes dos principais meios de comunicação do país. Milhares são os casos de crimes cometidos pelo país, contudo, o que se pretende enfatizar é que 


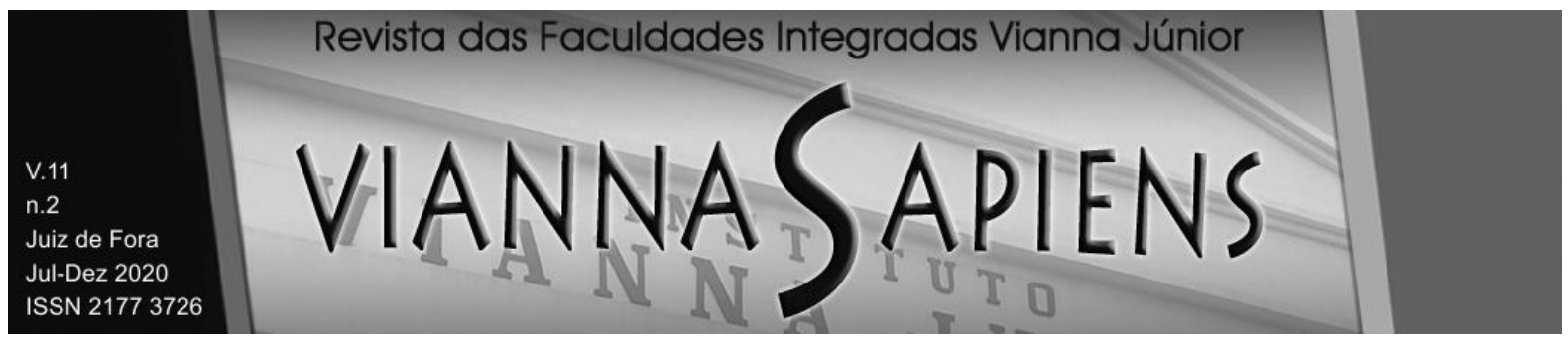

alguns casos são escolhidos e destacados pela mídia, de acordo com suas particularidades.

Neste ponto, cumpre ressaltar alguns casos que sofreram notória cobertura, desde o início até seu julgamento final. Ressalta-se, porém, que serão analisados apenas alguns dentre os inúmeros casos que sofreram influência midiática, considerando o objetivo e as limitações deste trabalho.

O início do populismo midiático no Brasil se deu com o homicídio da atriz Daniella Perez, ocorrido no ano 1992. Ela foi morta, no Rio de Janeiro, pelo ator Guilherme de Pádua e sua esposa Paula Thomaz, com 18 golpes de tesoura. À época dos fatos, o ator contracenava com a vítima na novela "De Corpo e Alma".

O caso tomou proporções exorbitantes por se tratar de um delito cometido contra a jovem protagonista da novela de maior audiência nacional, tendo intensa cobertura por parte de toda a imprensa brasileira. Tanto a Rede Globo de televisão quanto os demais meios de comunicação, tais como: a Revista Veja e o Jornal Folha de São Paulo (maiores meios de comunicação à época) se esforçaram, ao máximo, para mostrar as qualidades da vítima e denegrir os acusados. Foi feita uma amalgamação entre ficção e realidade, já que a personagem "Yasmim", interpretada por Daniella na novela, passava a imagem de que seria uma jovem pura e inofensiva, querida por todos (FREITAS, 2018).

O intuito de inflamar a opinião pública contra os acusados ficou claro na reportagem veiculada pela Rede Globo, no "Jornal Nacional”, em 29 de dezembro de 1992. Em menos de um dia do ocorrido, o jornal apresentou uma reportagem "resolvendo" o caso. Nitidamente tendenciosa e sensacionalista, apresentando uma reconstituição do crime não oficial, levando a opinião pública a considerar que o caso todo já havia sido solucionado e que estava perfeitamente delineado como ocorreu o crime e quem o cometeu (JN, 1992). Entretanto, após dois dias da exibição da reportagem, a mesma emissora, dessa vez no "Jornal Hoje", publicou uma matéria apresentando versão divergente da primeira, expondo que o crime fora cometido por duas pessoas, e não apenas uma, como havia sido previamente informado (JH, 1992). 


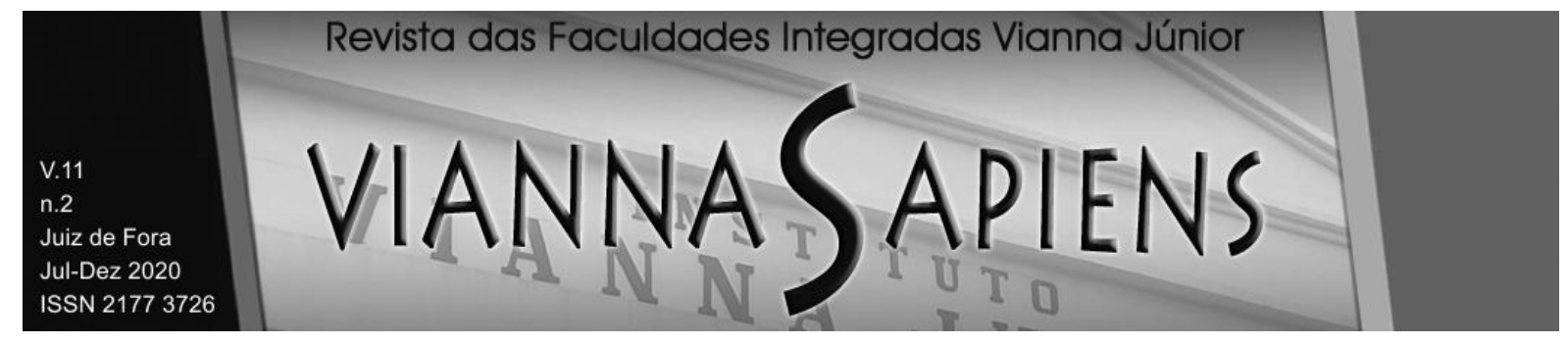

Assim sendo, fica evidente que a emissora, em momento algum tinha a intenção de informar a população, mas claramente teve o objetivo de transmitir os fatos visando a demonização dos acusados. Em adição, devido à forte influência midiática sobre o caso, os acusados, mesmo se tratando de réus primários e com bons antecedentes, ficaram sob custódia preventiva por aproximadamente quatro anos antes do julgamento definitivo (FREITAS, 2018), em total revelia à lei processual penal. Em outras palavras, não estavam presentes os fundamentos para a decretação da custódia preventiva.

Além disso, centenas de pessoas acompanharam tanto o julgamento de Guilherme como o de Paula; o veredito condenatório de Guilherme foi aplaudido de pé pelos presentes, o que realça que, de fato, a opinião pública escolheu um lado e estava torcendo pela punição (ELUF, 2007).

Outro caso que foi incansavelmente exposto pela mídia nacional foi o homicídio do casal Manfred e Marísia Von Richthofen, ocorrido em São Paulo. A filha do casal, Suzane Von Richthofen, com 18 anos de idade à época dos fatos, foi apontada junto com seu namorado, Daniel Cravinhos e o irmão dele, Cristian Cravinhos, como os responsáveis pela morte do casal. Posteriormente, os acusados confessaram o crime. O caso ganhou grande destaque devido a brutalidade e covardia como foi cometido. Na ocasião, foi amplamente divulgado que os acusados mataram as vítimas enquanto dormiam, com barras de ferro, e que a motivação do crime seria a vontade de Suzane ficar com a herança dos pais; nesse caso, a reportagem antecedeu o juízo cognitivo do Ministério Público e apontou a tipificação das condutas dos autores do delito como sendo homicídio "triplamente qualificado" (JN, 2002).

Observa-se que mais uma vez, antes mesmo de ser realizado o indiciamento dos acusados, a mídia já se incumbiu de fazer o julgamento por contra própria, com escopo de apresentar os suspeitos como culpados inquestionáveis. Destaca-se, ainda, que houve um pedido de televisionamento do julgamento, mas este não foi deferido pelo Tribunal de Justiça. No acórdão da negativa, consta o seguinte: 


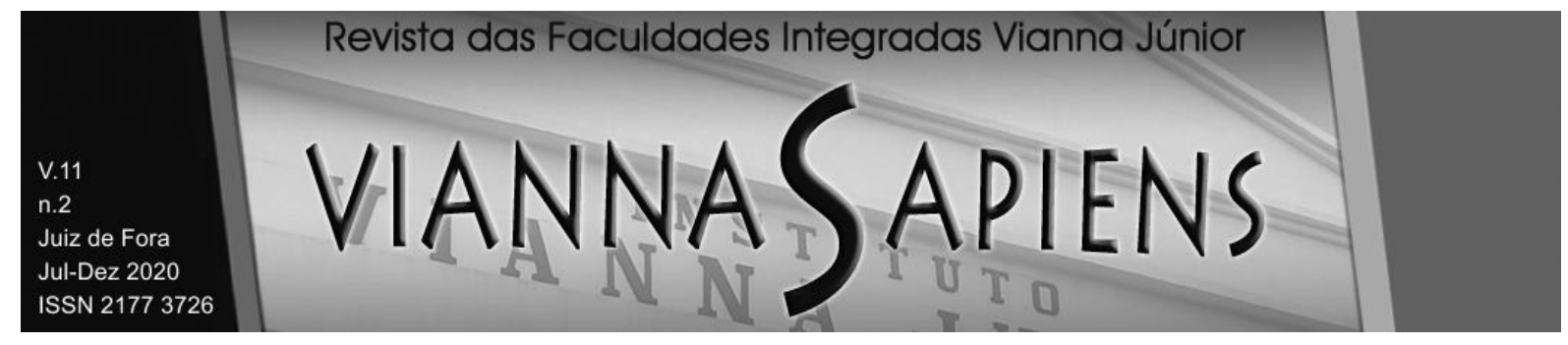

A publicidade do processo é uma garantia de que os atos nele praticados são feitos com lisura, daí a permanência das portas abertas de forma a que qualquer pessoa que esteja no Fórum possa ingressar e assistir à cerimônia solene. Daí a se pretender que todo o país possa assistir ao lamentável drama que se desenvolve no Plenário do Tribunal do Júri, inclusive com repasse de trechos para jornais internacionais, vai uma longa distância (HC 972.803.3/0-00).

Observa-se que até hoje, mesmo 17 anos após o crime, a mídia ainda acompanha a vida dos autores, principalmente de Suzane, sendo que todos os acontecimentos processuais, por mais ordinários que sejam, são transformados em notícia, como por exemplo, a reportagem feita pela Revista Época na qual expõe todos os acontecimentos da vida de Suzane em uma saída temporária (CAMPBELL, 2019).

O artigo 198, da Lei de Execuções Penais ${ }^{1}$, proíbe a exposição do preso à inconveniente notoriedade, durante o cumprimento da pena. Em adição, o artigo 4ํㅡㄴ, do mesmo diploma legal ${ }^{2}$, estabelece que o Estado deve recorrer a cooperação da comunidade nas atividades de execução da pena. Assim, ao realizar matérias sensacionalistas em relação a atos atinentes ao cumprimento da pena, como as saídas temporárias, por exemplo, a mídia presta um desserviço à sociedade, uma vez que tal conduta é contrária à reeducação e reinserção social do condenado.

Constata-se, portanto, que os autores de delitos de grande repercussão nacional não têm direito ao esquecimento de tais atos, pois a imprensa, constantemente, vasculha a vida de tais pessoas, com intuito de manter viva a chama do higienismo e exclusão social, impossibilidade a reintegração social dos acusados.

Igualmente emblemática é a morte de Isabella Nardoni, que ocorreu em 2008, também em São Paulo. A menina, de apenas cinco anos de idade, morreu ao cair da janela do sexto andar do prédio em que morava seu pai, Alexandre Nardoni, e sua

\footnotetext{
${ }^{1}$ Art. 198: É defesa ao integrante dos órgãos da execução penal, e ao servidor, a divulgação de ocorrência que perturbe a segurança e a disciplina dos estabelecimentos, bem como exponha 0 preso à inconveniente notoriedade, durante o cumprimento da pena.

Art. 40: O Estado deverá recorrer à cooperação da comunidade nas atividades de execução da pena e da medida de segurança.
} 


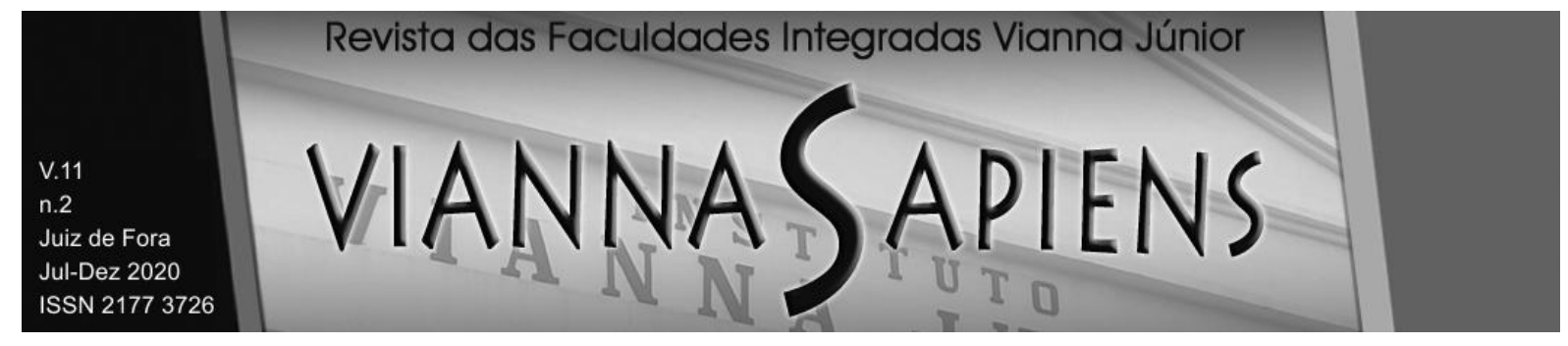

madrasta, Anna Carolina Jatobá. O pai e a madrasta foram acusados de terem jogado a menina com a intenção de matá-la. Ambos nunca admitiram a autoria delitiva e sustentaram a tese defensiva de que o crime fora cometido por um terceiro que entrou no apartamento enquanto eles estavam na garagem do condomínio. Não obstante, Alexandre e Anna Carolina foram julgados e condenados pelo Tribunal do Júri (FREITAS, 2018).

O fato de, nesse caso, os acusados não terem admitido a autoria delitiva, fez com que sua repercussão fosse ainda maior, uma vez que havia amplo espaço para debates e para a atuação da mídia como um órgão de investigação paralelo (FREITAS, 2018). Realça-se que, antes do julgamento, foi necessário que se elaborasse uma forte estrutura policial para evitar o linchamento dos acusados pela população, inflamada pelas notícias sensacionalistas veiculadas por diversos meios de comunicação. Assim, nota-se que mesmo sendo possível que o caso se tratasse de um acidente, os acusados já haviam sido condenados pela imprensa e, consequentemente, pela opinião pública, independentemente do resultado do julgamento perante o Poder Judiciário.

Já em 2010, o desaparecimento de Eliza Samúdio fez com que toda a atenção da imprensa voltasse para o que ficou conhecido como caso "goleiro Bruno". Eliza era publicamente conhecida por ter um envolvimento amoroso com Bruno Fernandes. Bruno e mais seis pessoas foram acusados e condenados pela prática de homicídio qualificado, ocultação de cadáver, sequestro e cárcere privado contra Eliza; além do sequestro e cárcere privado de seu filho, "Bruninho". Bruno, que antes figurava nos jornais esportivos como ídolo e capitão de um dos maiores times do futebol brasileiro, passou a ser demonizado pelos mesmos veículos de comunicação que o glorificava.

Assim, fica evidente a força que a imprensa exerce para formar o convencimento do espectador, e, por consequência, dos membros do Conselho de Sentença. As reportagens que divulgam a certeza do cometimento do crime, bem como de sua autoria, compostas por adjetivos negativos em relação aos acusados, acrescidas de clamor punitivo, certamente influem mais na convicção dos jurados do 


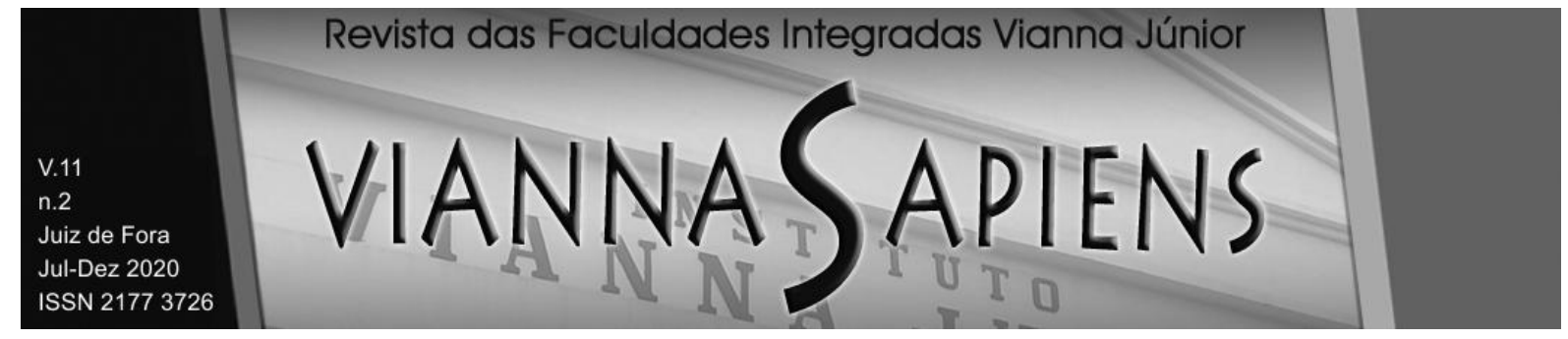

que as próprias provas produzidas nos autos e apresentadas em plenário (CUNHA, 2012).

Em todos os casos expostos, os acusados já chegaram ao banco dos réus condenados pela mídia e, por consequência, por seus juízes naturais. A veiculação massiva de notícias sensacionalistas, enxovalhando os autores já os tornam culpados perante a opinião pública, de modo que o julgamento perante o Poder Judiciário é notoriamente influenciado pela exposição midiática.

Especificadamente em relação ao pré-julgamento realizado no caso Daniella Perez, reflete Rogério Lauria Tucci (1999, p. 98), ao citar o ex-ministro da justiça, Marcio Thomaz Bastos:

[...] suponhamos que no júri dos supostos assassinos de Daniela Perez um ou dois mais réus fossem inocentes. Ele, ela, ou eles teriam alguma chance de absolvição, depois da operação de 'linchamento' montada pela mãe da vítima com o apoio da Rede Globo e de toda a mídia nacional? Claro que a resposta é negativa.

Em resumo, restou demonstrado que em todos os casos analisados a imprensa teve papel fundamental na condenação dos acusados; em todos a cobertura foi feita de maneira sensacionalista e parcial.

\subsection{Consequências legais da intervenção midiática sobre o veredito final}

A interferência da mídia nos crimes de competência do Tribunal do Júri possui um caráter negativo, pois é extremamente danosa e pode gerar sérias violações a direitos fundamentais do acusado. Isso porque, alguns princípios processuais penais constitucionais são desrespeitados, maculando o devido processo legal. O princípio da presunção de inocência, por exemplo, é firmemente desrespeitado pelos meios de comunicação em massa, uma vez que, na ânsia de vender uma notícia, há divulgação de matérias sensacionalistas condenando os suspeitos antes mesmo de seu julgamento, ou até antes do indiciamento e do oferecimento da denúncia, pelo Ministério Público. Igualmente, é notória a violação do princípio constitucional do 


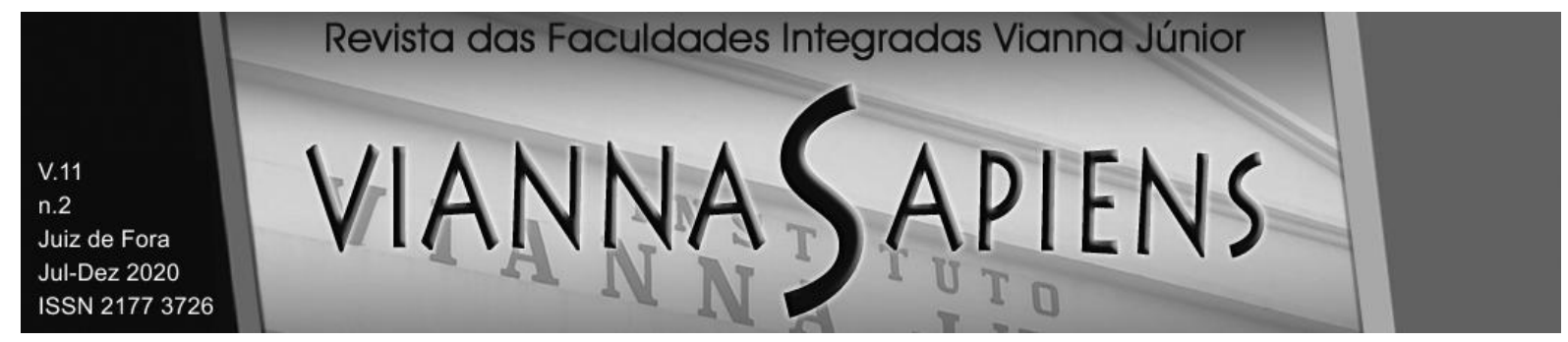

devido processo legal, considerando que o indivíduo passa por um julgamento midiático, no qual para a "opinião publicada", este já é considerado culpado, independentemente do desenrolar de seu julgamento, perante o Poder Judiciário.

Por isso, a liberdade de imprensa deve encontrar restrições, principalmente quando se esbarra com os direitos à intimidade, à vida privada, à honra e à imagem das pessoas, porquanto são direitos agasalhados pela Carta da República, de 1988, compondo um complexo de direitos fundamentais. No entanto, há uma ignorância a essa barreira, expondo obstinadamente a vida privada dos acusados.

Importa, ainda, ressaltar que o Tribunal do Júri foi instituído pela Constituição Federal, de 1988, com o objetivo de garantir ao indivíduo, acusado pela prática de delitos dolosos contra a vida, o julgamento por seus pares, com o intuito de permitir maior equidade, se comparado ao julgamento proveniente de um magistrado togado.

O Tribunal do Júri foi inserido como cláusula pétrea na Lei Maior justamente para evitar o arbítrio estatal, ficando a decisão final nas mãos de pessoas da comunidade, mais próximas da realidade do acusado. Mas, a realidade que se pousa aos fatos é outra, pois o julgamento realizado pelo Tribunal do Júri, muitas vezes, é eivado de sérias distorções, desde a composição do Conselho de Sentença, o qual, na grande maioria das vezes, é composto por pessoas de classes privilegiadas para julgar pessoas marginalizadas, até a ausência de meios que impeçam que as decisões sejam tomadas sem ceder às pressões externas da opinião pública inflamada pela mídia (FREITAS, 2018).

Com isso, o princípio geral vinculado ao brocado in dubio pro reo é desrespeito, uma vez que, levando em consideração a pressão feita pela sociedade e pelos meios de comunicação, o jurado, mesmo em dúvida, acaba decidindo desfavoravelmente ao réu e favorável ao prévio libelo midiático, dando incidência ao in dubio pro societate.

Seguindo esta esteira de raciocínio, os direitos fundamentais devem sempre ter seus núcleos preservados, sob pena de perderem a eficácia e deixarem de ser considerados como essenciais. Neste norte, Sarlet (2014, p. 206) ensina que: 


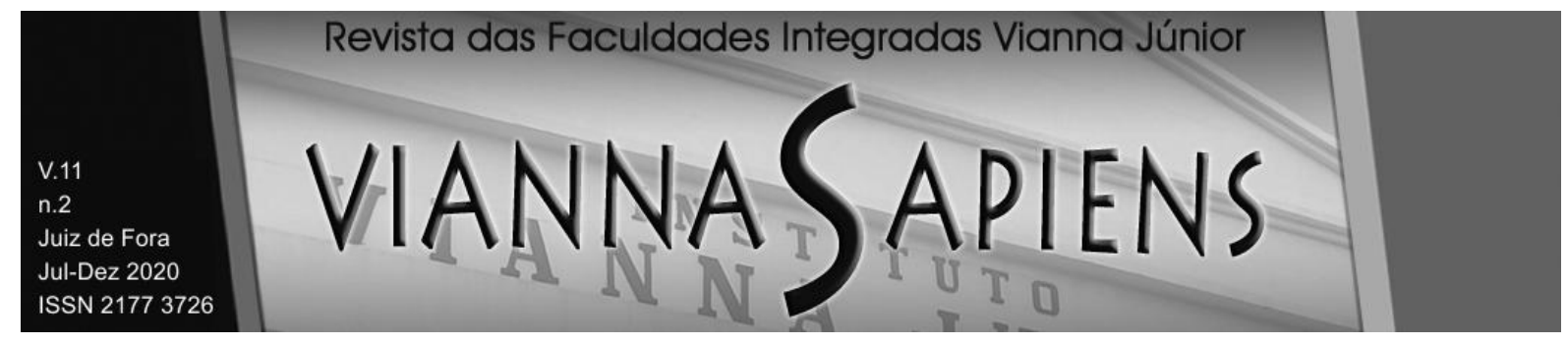

A garantia de proteção do núcleo essencial dos direitos fundamentais aponta para a parcela do conteúdo de um direito sem a qual ele perde a sua mínima eficácia, deixando, com isso, de ser reconhecível como um direito fundamental.

Isto posto, considerando que o objetivo da instituição do Tribunal do Júri, enquanto componente do complexo de direitos fundamentais, não é alcançado, resta inequívoca a necessidade de criação de mecanismos inibitórios à exposição midiática exagerada bem como o mister da adoção de medidas para garantir ao acusado um julgamento justo e imparcial.

\subsection{A renúncia ao júri popular como garantia do devido processo legal: a luta por um juiz imparcial}

A interferência da imprensa na opinião pública acarreta graves violações ao devido processo legal. Por isso, é imprescindível que se apresente alternativas para garantir que o acusado seja julgado da maneira justa e imparcial.

Admitir o desaforamento do processo, previsto no art. 427, do Código de Processo Penal, como mecanismo suficiente para estancar o problema, apenas terá eficácia nos casos de repercussões regionais ou locais, pois nos casos de repercussão nacional o instituto do desaforamento mostra-se inútil para obtenção de um julgamento justo e imparcial, por conta da penetração nas matérias jornalísticas. Neste sentido, é o magistério de Vladimir Aras (2010, p. 5):

Talvez um dos instrumentos mais eficientes para assegurar julgamento justo por um júri imparcial seja o instituto do desaforamento [...]. Contudo, num caso como o de Isabella Nardoni dificilmente o desaforamento resolveria o problema do viés condenatório do tribunal, evitando a formação de um júri viciado.

Deste modo, apenas transferir o julgamento de um caso com grande cobertura midiática para outra comarca não resolveria o problema em relação à imparcialidade dos jurados. 


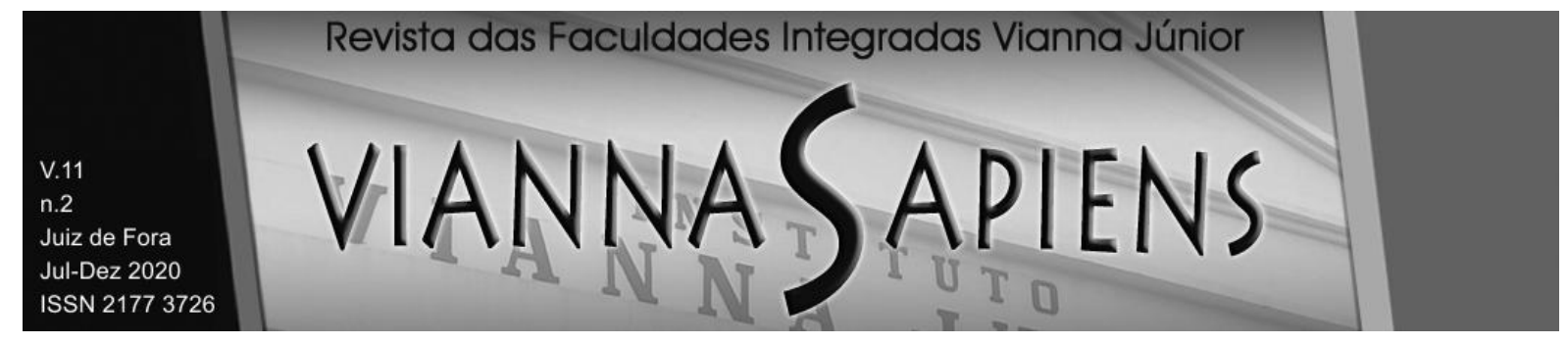

Também não há que se defender a imposição de censura aos meios de comunicação, cuja liberdade é uma garantia constitucional, já que a liberdade de manifestação do pensamento é assegurada pela Lei maior. Neste norte, o Supremo Tribunal Federal já manifestou a repulsa pela censura, no ano de 2009, ao realizar o julgamento da Arguição de Descumprimento de Preceito Fundamental (ADPF) 130/2009. Da inteligência desse julgado, extrai-se que é vedada a censura, devendo a liberdade de imprensa ser preservada, sem prejuízo de que abusos sejam repudiados pelo Poder Judiciário na análise das responsabilidades penal e civil.

Com isso, considerando a ineficiência do desaforamento e o repúdio à censura prévia, resta explorar a hipótese de renúncia do acusado ao julgamento pelo Tribunal do Júri.

De início, destaca-se que no ordenamento jurídico brasileiro não há previsão expressa acerca do tema, de modo que é necessário utilizar-se do direito comparado, especialmente do direito estadunidense, como fonte para solucionar a problemática. $\mathrm{Na}$ maior parte dos estados norte-americanos o acusado tem a prerrogativa de recusar livremente o julgamento pelo tribunal do júri (right to waive trial by jury), podendo optar por ser julgado por um juiz togado (ARAS, 2010).

Analisando-se o texto constitucional brasileiro, conforme já exposto, observase que o Tribunal do Júri foi instituído pelo artigo 5, inc. XXVIII, da Constituição Federal, e integra o conjunto de direitos e garantias individuais. Apesar disso, a Carta da República determina que seus regramentos sejam dispostos por lei ordinária, de modo que se abre margem para sua interpretação, desde que sempre respeitados o sigilo das votações, a plenitude de defesa, a soberania dos veredictos e a competência mínima para o julgamento de crimes dolosos contra a vida.

A parte majoritária da doutrina brasileira é contrária à renúncia de direitos constitucionais fundamentais, sob 0 argumento de que são irrenunciáveis, inalienáveis e imprescritíveis (SILVA, 2010). Porém, a corrente no sentido contrário tem ganho força, defendendo que, em muitos casos, a irrenunciabilidade dos direitos fundamentais é questionada (SILVA, 2008), ou seja, é possível opor-se a direitos e garantias constitucionais, porquanto tais atributos constitucionais foram criados como disposições positivas ao sujeito. Destarte, qualquer direito ou garantia 


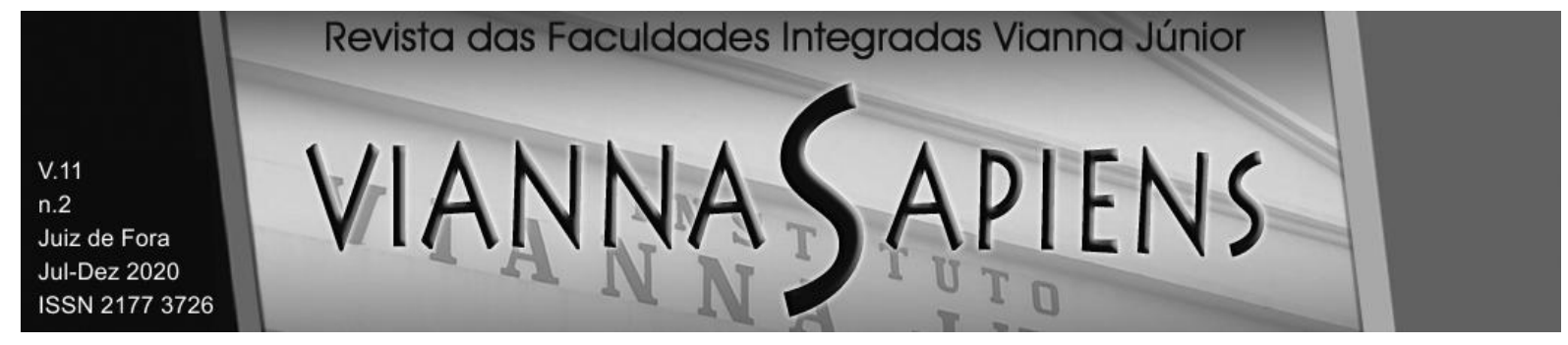

fundamental que, se aplicado ao caso concreto, provoque lesão a seu titular, deve ser afastado. A título exemplificativo, destaca-se que a própria Constituição Federal, em seu artigo 5o, inc. Xl, estabelece a hipótese de renúncia ao direito da inviolabilidade do domicílio, por meio do consentimento do morador.

Importa ressaltar que a Carta Magna estabelece múltiplos direitos fundamentais, sendo possível a incidência de colisão entre eles. Desta forma, havendo colisão, é necessário aplicar-se o princípio da ponderação, de acordo com - caso concreto, sendo que um deles será sobreposto pelo outro, e, consequentemente gerará a renúncia daquele (DIAS, 2010). Portanto, é corretamente possível a renúncia a direitos fundamentais, desde que seja feita por seu titular, sendo resultado de sua autonomia e não contenha vícios ou qualquer tipo de constrangimento. A renúncia deve ocorrer visando um benefício autêntico ao titular de tal direito, mesmo que seu favorecimento ocorra de maneira indireta (ADAMY, 2018).

O artigo 5ํ, da Lei Maior, prevê a inviolabilidade dos direitos fundamentais. Tal ditame tem o condão de estabelecer que estes direitos não podem ser ilegitimamente violados por terceiros. Por outro lado, a inviolabilidade não implica que os direitos sejam indisponíveis. Acerca da possibilidade da renúncia de direitos fundamentais, aduz Jorge Reis Novais (2006, p. 235):

Da própria dignidade da pessoa humana e do princípio da autonomia e de autodeterminação individual - que integram e moldam de algum modo o cerne de todos e de cada um dos direitos fundamentais decorre o poder de o titular dispor dessa posição de vantagem, inclusivamente no sentido de a enfraquecer, quando desse enfraquecimento, e no quadro da livre conformação da sua vida, espera retirar benefícios que de outra forma não obteria. Nesse sentido, a renúncia é também uma forma de exercício do direito fundamental, dado que, por um lado, a realização de um direito fundamental inclui, em alguma medida, a possibilidade de se dispor dele, inclusive no sentido de sua limitação, desde que esta seja uma expressão genuína do direito de autodeterminação e livre desenvolvimento da personalidade individual, e porque, por outro lado, através da renúncia o indivíduo prossegue a realização de fins e interesses próprios que ele considera, no caso concreto, mais relevantes que os fins realizáveis através de um exercício positivo do direito 


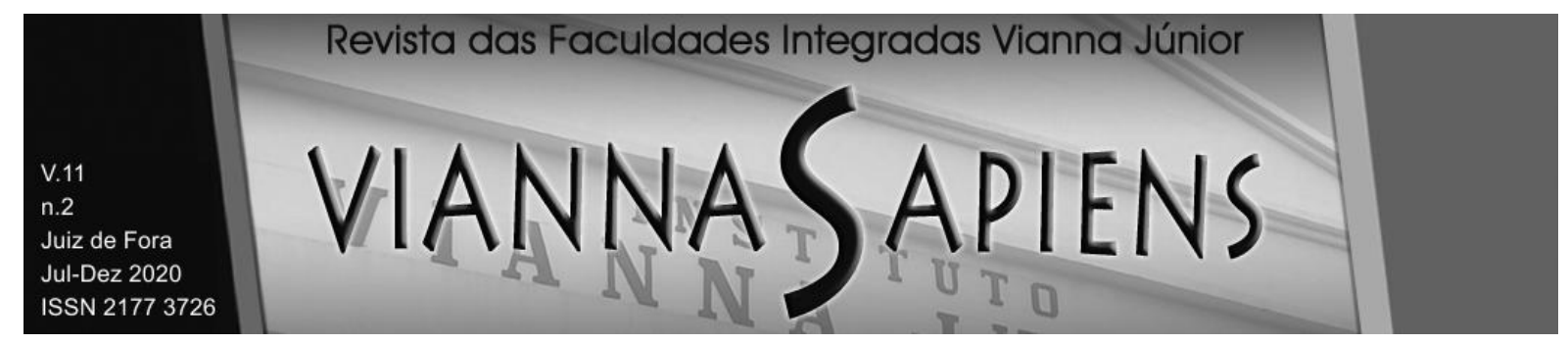

Destarte, pelo que se extrai da lição acima colacionada, é plenamente possível a renúncia quando esta for mais relevante para a concretização de interesses próprios do que o próprio exercício do direito em questão.

Nesta esteira de raciocínio, Diaulas Costa Ribeiro (2019) reflete acerca da compulsoriedade do Tribunal do Júri. Para ele, por se tratar de um direito individual, por classificação constitucional não pode, consequentemente, ser imposto. Assim, se o indivíduo tem a faculdade de abdicar de certas prerrogativas processuais como os direitos de se manter em silêncio e de recorrer das decisões, também é possível que opte pela renúncia ao foro popular, considerando que se trata de um instituto criado essencialmente em seu favor, não podendo the ser prejudicial.

O julgamento, pelo Tribunal do Júri, trata de uma garantia constitucional dada ao acusado de ser julgado por seus pares, como forma de avalizar uma apreciação equânime. Por outro lado, quando o júri se torna parcial e atenta contra às garantias individuais do acusado e sua condenação é praticamente certa antes mesmo do início do julgamento, perde sua essência, passando a ser um instrumento de opressão e não de garantia de direitos fundamentais.

Nesses casos, socorrer-se de um julgamento realizado por juízes togados pode ser um caminho melhor, uma vez que a interferência midiática sobre os magistrados, ainda que existente, ocorre em menor grau, tendo em vista que estes são pessoas preparadas para avaliar as provas do caso em questão, somado ao fato de que todas as suas decisões devem ser fundamentadas, o que, em tese, impede arbítrios e condenações baseadas em anseios populares (FREITAS, 2018).

Não bastasse isso, imprescindível destacar que, como já exposto, vige no Tribunal do Júri o princípio da soberania dos veredictos, de modo que as decisões dele apenas poderão ser revistas em situações especialíssimas (art. 593, inc. III, do CPP), o que, sem dúvida, em casos de grande repercussão midiática, resulta em prejuízos ao acusado, na medida em que muitas vezes o duplo grau de jurisdição esvaziar-se-á no primeiro grau. Por outro lado, o mérito da decisão do juiz togado comporta recursos aos tribunais superiores, inclusive para absolver o acusado; fato que garante maior segurança de que o resultado final do processo seja imparcial, 


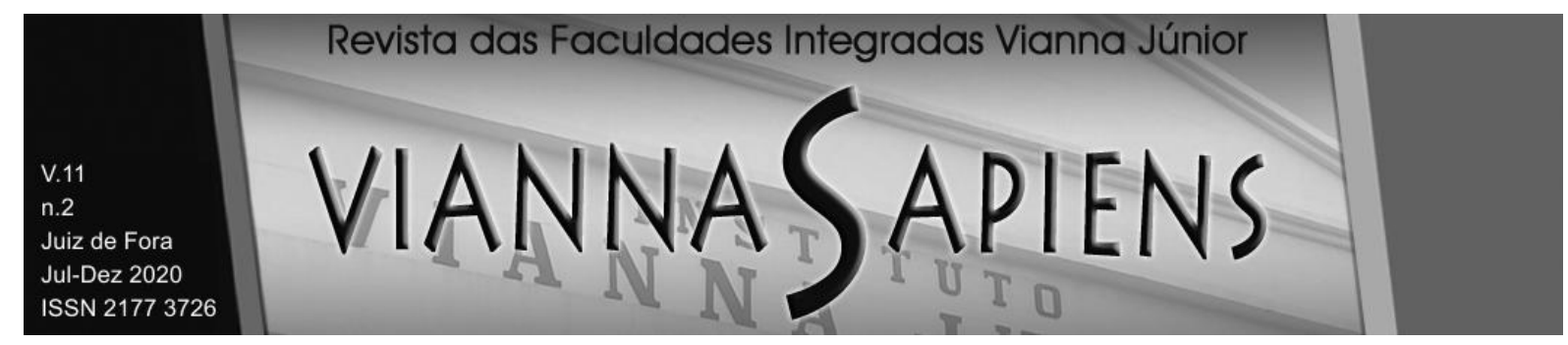

tendo em vista que até o trânsito em julgado da decisão, o mérito poderá ser revisado por um colegiado de desembargadores, que tem competência para reformar a decisão e absolver o acusado.

Em síntese, tendo vista a ineficácia do desaforamento em casos de proporções nacionais ou até mesmo globais, bem como a impossibilidade da prática de censura dos meios de comunicação para que se evite o sensacionalismo em torno de casos relativos ao Tribunal do Júri, a renúncia ao julgamento popular é uma boa alternativa.

\section{CONSIDERAÇÕES FINAIS}

O Tribunal do Júri tem alicerce constitucional e integra o conjunto de direitos fundamentais. Em tese permite que, ao cometer um crime doloso contra a vida, consumado ou tentado, o indivíduo seja julgado por seus pares, evitando assim arbítrios estatais e favorecendo uma apreciação equânime. No entanto, o Tribunal do Júri é, muitas vezes, utilizado como um instrumento de opressão e exclusão, manejado pela cobertura midiática a fim de decidir de acordo com anseios populares, inflamados por coberturas apaixonadas e sensacionalistas.

Destaca-se que os grandes meios de comunicação em massa são, na verdade, grandes empresas, concentradas nas mãos de pouquíssimas pessoas, as quais buscam sempre propagar a versão que lhes é mais favorável e lucrativa. No anseio de vender notícias, a imprensa seleciona casos que despertam a atenção e curiosidade do público e cria em torno deles um verdadeiro espetáculo midiático. Neste sentido, os casos atinentes ao Tribunal do Júri são os favoritos, principalmente quando envolvem pessoas célebres ou quando os crimes cometidos possuem elementos que alimentem uma narrativa dramática.

Desse modo, além de expor os casos incansavelmente, a mídia realiza também um pré-julgamento, pelo qual influi na opinião pública, alimentando o clamor pela punição, muitas vezes transformando os suspeitos e acusados em assombros, 


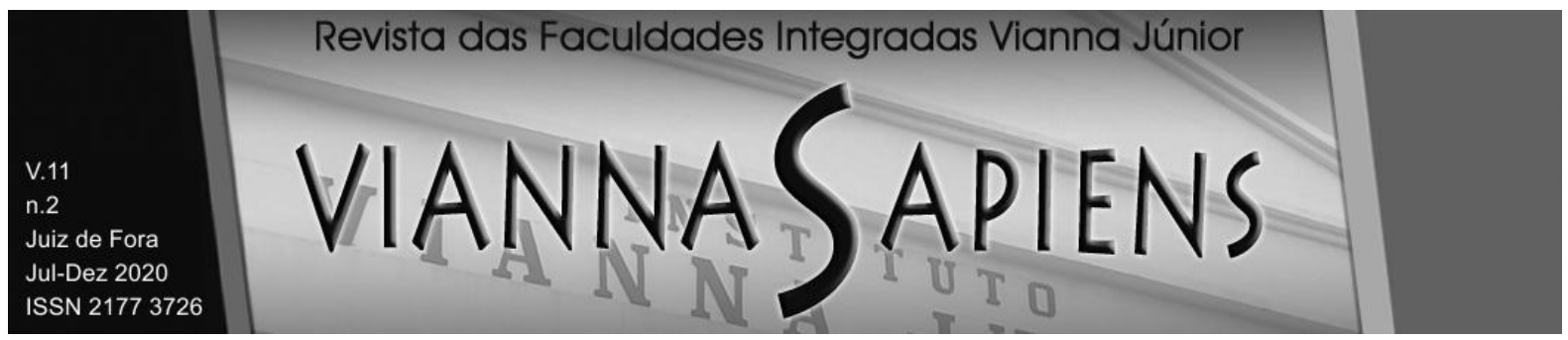

criando o lado do bem e o lado do mal. Somado a isso, ainda há as redes sociais que colaboram no prévio juízo da causa.

Com isso, a mídia extrapola os limites da liberdade de imprensa, entrando em conflito com direitos fundamentais, como a intimidade, a vida privada, a honra e a imagem dos acusados.

Ao estabelecer a cultura do medo, a imprensa passa a influir nas decisões do Tribunal do Júri, uma vez que, por meio de coberturas sensacionalistas, sugestiona os jurados a optarem pela condenação, como forma de satisfação dos anseios da opinião publicada. Sendo assim, o jurado que comporá o Conselho de Sentença já chegará ao julgamento inclinado a condenar o acusado, tolhendo, dessa forma, o exercício da plenitude de defesa. Por tal razão, é importante que seja criado mecanismo que garanta ao acusado, que esteja em nessa situação, o respeito ao devido processo legal.

Hastear a bandeira do desaforamento como forma de solucionar o problema, nos casos de repercussão nacional, é inócuo, tendo em vista a globalização dos noticiários. Da mesma forma, não há que se falar em censura prévia dos meios de comunicação, pois a liberdade de imprensa é fundamental no Estado Democrático de Direito.

Assim sendo, recorrendo ao direito comparado, em casos excepcionais, a adoção da possibilidade de renúncia, por parte do acusado, ao julgamento pelo Tribunal do Júri é medida que se impõe, afastando, ou ao menos diminuindo, dessa forma, interferência midiática nas decisões de crimes dolosos contra a vida.

\section{REFERÊNCIAS}

ADAMY, Pedro. Curso de Direito Constitucional. São Paulo: Tirant, 2018.

ANDRADE, Fábio Martins de. Mídia e o Poder Judiciário: a influência dos órgãos da mídia no processo penal brasileiro. Rio de Janeiro: Lumen Jris, 2007. 


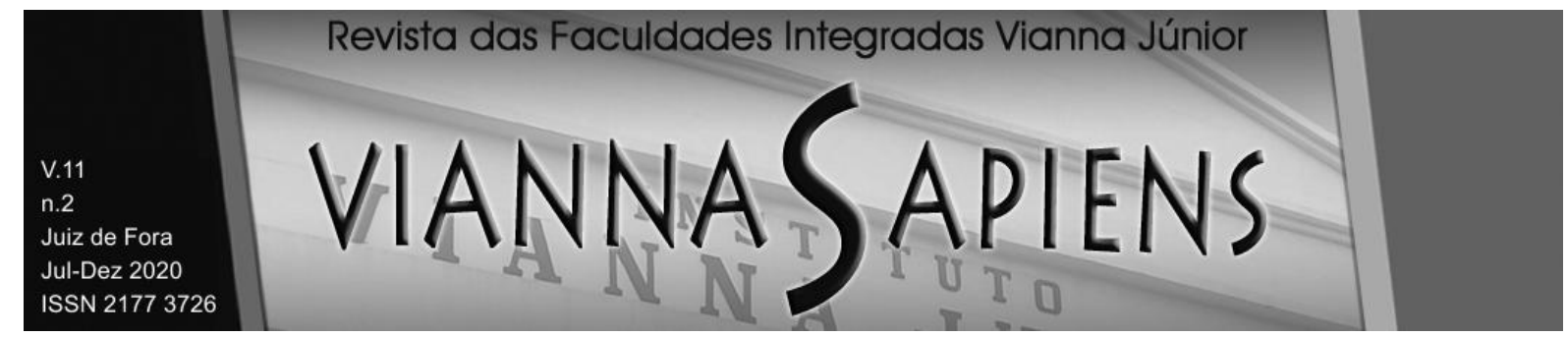

ARAS, Vladimir. Renúncia ao julgamento pelo júri no processo penal brasileiro. Revistas Custos Legis, 2010.

AVENA, Norberto Cláudio Pâncaro. Processo Penal. 9 ed. Rio de Janeiro: Forense. São Paulo: Método, 2017.

BATISTA, Nilo. Mídia e sistema penal no capitalismo tardio. Revista Brasileira de Ciências Criminais, São Paulo. 2003.

BONFIM, Edilson Mougenot. Curso de Processo Penal. 9. ed. São Paulo: Saraiva, 2014.

BUDÓ, Marília de Nardi. Mídia e teoria da pena: crítica à teoria da prevenção geral positiva para além da dogmática penal. In: Revista Brasileira de Ciências Criminais, ano 21, n.101. São Paulo: RT, 2013.

CAMPBELL, Ullisses. A rotina de suzane von richthofen em uma de suas 'saidinhas' da prisão. Época. 24/10/2019. Disponível em <https://epoca.globo.com/brasil/arotina-de-suzane-von-richthofen-em-uma-de-suas-saidinhas-da-prisao-24037723>. Acesso em 29 de outubro de 2019.

CUNHA, Luana Magalhães de Araújo. Mídia e o processo penal: a influência da imprensa nos julgamentos dos crimes dolosos contra a vida á luz da constituição de 1988. Revista Brasileira de Ciência Criminais. №. 94. São Paulo. Revista dos Tribunais. 2012.

DIAS, Roberto. A dignidade da pessoa humana e o testamento vital no ordenamento constitucional brasileiro. In: BERTOLDI, Márcia Rodrigues; OLIVEIRA, Kátia Cristine Santos de (Coord.). Direitos fundamentais em construção: estudos em homenagem ao ministro Carlos Ayres Britto. Belo Horizonte: Fórum, 2010

ELUF, Luiza Nagib. A paixão no banco dos réus: casos passionais célebres. 3. ed. São Paulo: Saraiva, 2007.

FREITAS, Paulo. Criminologia Midiática e Tribunal do Júri: a influência da mídia e da opinião pública na decisão dos jurados. 2ª Ed. Niterói, RJ: Impetus, 2018. 


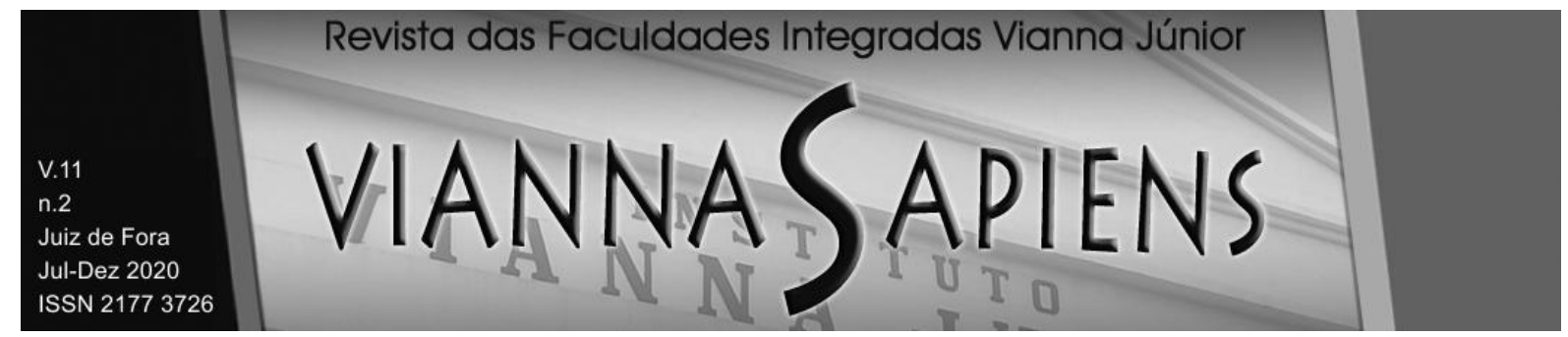

JORNAL HOJE, 31 de dezembro de 1992. Disponível em:

$<$ https://www.youtube.com/watch?v=Uu2RCJAEEzU>. Acesso em 28 de outubro de 2019.

JORNAL NACIONAL, 8 de novembro de 2002. Disponível em $<$ https://www.youtube.com/watch?v=bly7Zi0OGls>. Acesso em 29 de outubro de 2019.

LIRA, Rafael de Souza. Mídia Sensacionalista: o segredo de justiça como regra. Rio de Janeiro: Forense, 2014.

NOVAIS, Jorge Reis. Direitos fundamentais: trunfos contra a maioria. Coimbra: Coimbra Editora, 2006.

PINA, Sara. Mídia e leis penais. Coimbra: Almedina, 2009.

RIBEIRO, Diaulas Costa. Júri: um direito ou uma imposição? Disponível em: $<$ http://www.diaulas.com.br/artigos.asp?id=213\&p_ch=>. Acesso em: 31 de outubro de 2019.

SARLET, Ingo Wolfgang. Notas Introdutórias ao sistema constitucional de direitos e deveres fundamentais. In: CANOTILHO, J.J. Gomes; MENDES, Gilmar F.; SARLET, Ingo W.; STRECK, Lenio L. (Coords.) Comentários à constituição do Brasil, 2014.

SCHREIBER, Simone. A publicidade opressiva dos julgamentos criminais. Rio de Janeiro. Editora Renovar, 2010.

SHEPPARD V. Maxwell. United States Supreme Court. 384 U.S. 333. Argued February 28, 1966 Decided June 6, 1966.

SILVA, José Afonso da. Curso de Direito Constitucional Positivo. São Paulo: Malheiros, 2010.

SILVA, Virgílio Afonso da. A constitucionalização do direito: os direitos fundamentais nas relações entre particulares. São Paulo: 2008. 


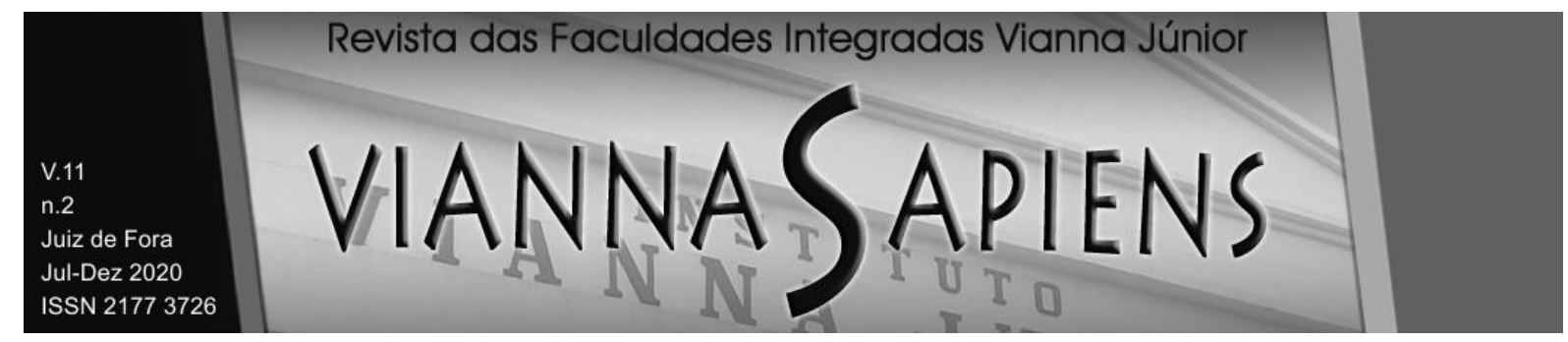

TUCCI, Rogério Lauria. Direitos e Garantias Individuais no Processo Penal Brasileiro. São Paulo: Saraiva, 1999.

VIEIRA, Ana Lúcia Menezes. Processo Penal e Mídia. São Paulo: Revista dos Tribunais, 2003.

ZAFFARONI, Eugenio Raúl. A palavra dos mortos: conferência de criminologia cautelar, São Paulo: Ed. Saraiva, 2012.

Recebido em 11/04/2020

Publicado em 31/08/2020 